\title{
KAPITALENS PRODUKTIVITET
}

\section{Karl Marx}

\section{A) ALT SAMFUNDSMAESSIGT ARBEJDES PRODUKTIVKREFTER SYNES AT VERE KAPITALENS PRODUKTIVKREFTER.}

Vi har set, ikke blot hvordan kapitalen producerer, men også, hvordan den fremgår fra produktionsprocessen som en væsenalig forandret relation, hvordan den udvikler sig i denne proces. På den ene side omdanner den produktionsmåden, på den anden side er den forandrede produktionsmåde samt et bestemt trin af de materielle produktivkræfters udvikling grundlaget og betingelsen - forudsætningen for dens egen skabelse.

Da det levende arbejde - gennem udvexlingen af kapital og arbejde - er inkorporeret i kapitalen, synes at være en virksomhed, som tilhører denne, så snart arbejdsprocessen begynder, fremtræder det samfundsmæssige arbejdes produktivkræfter som kapitalens produktivkræfter, ganske som arbejdets almene samfundsmæssige karakter - i form af penge - viser sig som en tings egenskaber. Således fremtræder nu det samfundsmæssige arbejdes produktivkraft og dens forskellige former som produktivkraft for kapital, for objektiveret arbejde, for de objektive arbejdsbetingelser, der - personificeret i kapitalisten - konfronterer det levende arbejde $i$ en sådan selvstændiggjort form. Det drejer sig her igen om den venden-op-og-ned på forholdene, som vi allerede ved betragtningerne over penge har betegnet som fetischisme.

Kapitalisten selv er kun magthaver i sin egenskab af kapitalens personificering. (I italiensk bogholderi konfronteres han som person stedse med sin rolle som kapitalist, som personificeret kapital, for hvilken han kun fremtræder som sin egen kapitals privatkonsument og skyldner.)

Kapitalens produktivitet består først og fremmest - selv når vi blot betragter det formelle underordningsforhold, der består mellem arbejde og kapital - i tvangen til merarbejde, til arbejde ud over den umiddelbare nødvendighed, en tvang, som den kapitalistiske produktionsmåde deler med tidligere produktionsmåder, men som den udøver og fuldender på en for produktionen gunstigere måde.

Selv når vi blot betragter dette formelle forhold - den kapitalistiske produktions almene form, som den mindre udviklede produktionsmåde har til fælles med den mere udviklede - synes produktionsmidlerne, de objektive arbejdsbetingelser - arbejdsmaterialer, arbejdsredskaber (\& levnedsmidler) - 
ikke at være underlagt arbejderen, men de underlægger sig tværtimod ham. Og derved er de kapital. Kapital anvender arbejde. De er ikke et middel for hans produktion, hvad enten det drejer sig om produktion af umiddelbare subsistensmidler, eller af bytteobjekter, varer. Men han er et middel for dem; dels bevarer han deres værdi, dels forøger han den, d.v.s. han gør deres værdi større, idet de absorberer merarbejde.

Allerede $i$ sin enkelhed er dette forhold vendt op og ned, er det et udtryk for personificering af ting og tingsliggørelse af personer, og dette adskiller denne produktionsform fra alle tidligere: at kapitalisten ikke $i$ en eller anden personlig egenskab behersker arbejderen, men at han kun behersker ham $i$ den udstrækning, han er "kapital"; hans herredømme er kun det objektiverede arbejdes herredømme over det levende, arbejdsprodukternes herredømme over arbejderen selv.

Mere kompliceret og tilsyneladende mere mystisk bliver forholdet med udviklingen af den kapitalistiske produktionsmåde, idet da ikke blot disse umiddelbart materielle ting som alle er produkter af arbejdet: de som brugsværdi betragtet objektive arbejdsbetingelser, den som bytteværdi betragtet objektiverede almene arbejdstid eller penge - stiller sig på bagbenene overfor arbejderen og konfronterer ham som kapital; også de forskellige former for samfundsmæssigt udviklet arbejde: kooperation, fabriksarbejde ( $i$ betydningen: organiseret samfundsmæssigt arbejde med maskiner som den materielle basis) , fremtræder som udviklingsformer for kapital, og de produktivkræfter, som udvikles af disse former for samfundsmæssigt arbejde, og derfor også videnskab og naturkræfter, fremtræder som kapitalens produktivkræfter. Kooperationens enhed, arbejdsdelingens kombination, anvendelsen af naturkræfter og videnskab og arbejdsprodukter $i$ produktionsmaskineriet - alt dette konfronterer den enkelte arbejder som noget fremmed og objektivt, som blotte existensformer for de arbejdsredskaber, som er uafhængige af ham, som behersker ham, og som selv i deres enkle, anskuelige form som materialer, instrumenter etc. konfronterer ham som kapitalens og derfor også som kapitalistens funktioner.

De samfundsmæssige former for hans eget arbejde eller formerne for hans eget samfundsmæssige arbejde er relationer, som dannes ganske uafhængigt af den enkelte arbejder; arbejderen underlægges kapitalen, bliver et element $i$ de samfundsmæssige formationer, men disse tilhører ham ikke. De konfronterer ham derfor som kapitalens egne former, som tilhørende, ikke deres forenede arbejdskraft, men derimod kapitalen og den kombination, som udspringer af og er inkorporeret $i$ denne. Og dette antager en desto virkeligere form, jo mere på den ene side hans arbejdskraft modificeres $i$ disse relationer, således, at den i sin selvstændige form - altså udenfor denne kapitalistiske sammenhæng bliver afmægtig, at hans selvstændige produktionsevne brydes, og jo mere på den anden side - med udviklingen af maskiner - arbejdsbetingelserne også teknologisk synes at beherske arbejdet og samtidig erstatte det, undertrykke det, gøre det overflødigt i sine selvstændige former.

I denne proces konfronteres han af den samfundsmæssige karakter af sit på en vis måde kapitaliserede arbejde - f.ex. synes maskinerne, de synlige arbejdsprodukter, at beherske arbejdet - men det samme gælder naturligvis naturkræfterne og ikke mindst videnskaben, som er produktet af den almene historiske udvikling i sin abstrakte kvintessens: de konfronterer ham som kapitalens magter. De adskiller sig i virkeligheden fra den enkelte arbejders evner og kendskab, og skønt også de - m.h.t. deres udspring - er produkter af arbejdet, synes de at være inkorporeret i kapitalen overalt, hvor de optræder i arbejdsprocessen. Den kapitalist, som anvender en maskine, behøver ikke at forstå den. Men i maskinen optræder den realiserede videnskab som kapital overfor arbejderen. Og faktisk synes al anvendelse af videnskab, naturkræfter og arbejdsprodukter $i$ store mængder - anvendelse, baseret på samfundsmæssigt arbejde - kun at være 
et middel for udbytning af arbejde, for tilegnelse af merarbejde, at være kræfter, som tilhører kapitalen overfor arbejdet. Kapitalen anvender naturligvis kun alle disse midler for at udbytte arbejdet, men for at udbytning kan finde sted, må de anvendes $i$ produktionen. Og således fremtræder arbejdets samfundsmæssige produktivkræfters udvikling og betingelserne herfor som kapitalens handlinger, overfor hvilke den enkelte arbejder ikke blot forholder sig passiv, men som direkte står $i$ et modsætningsforhold til arbejderen.

Kapitalen selv optræder i dobbelt skikkelse, da den består af varer:

1 ) Som bytteværdi (penge), men som værdi, der yngler, værdi, som skaber værdi, voxer som værdi, modtager en tilvæxt, fordi den er værdi. Dette reduceres til byttet af et givet kvantum objektiveret arbejde mod et større kvantum levende arbejde.

2 ) Som brugsværdi, og her fremtræder den $i$ overensstemmelse med de bestemte forhold $i$ arbejdsprocessen. Men netop her viser den sig ikke blot som de arbejdsmaterialer og arbejdsredskaber, hvortil arbejdet er knyttet, som inkorporerer arbejdet, men derved også som den samfundsmæssige kombination af arbejde og den hertil svarende udvikling af arbejdsredskaberne. Først den kapitalistiske produktion udvikler arbejdsprocessens betingelser kraftigt, idet disse rives løs fra den enkelte selvstændige arbejder, men den udvikler dem som en magt, der behersker arbejderen, og som er ham fremmed.

Således bliver kapitalen et særdeles mystisk væsen.

Kapitalen er altså produktiv:

1) Som tvang til merarbejde

2) Gennem absorbering og tilegnelse (personificering) af det samfundsmæssige arbejdes produktivkræfter og af almene samfundsmæssige produktivkræfter som videnskab.

Det spørgsmål melder sig: hvordan viser arbejdet sig som produktivt arbejde overfor kapitalen, når arbejdets produktivkræfter er overført til kapitalen? Og når den samme produktivkraft ikke kan tælle med to gange, én gang som arbejdets og én gang som kapitalens produktivkraft? (Arbejdets produktivkræfter = kapitalens produktivkræfter. Men arbejdskraftens produktivitet udtrykkes ved forskellen mellem dens værdi og dens realisering.)

\section{B) PRODUKTIVT ARBEJDE I DET KAPI- TALISTISKE PRODUKTIONS SYSTEM.}

Kun den borgerlige bornerthed, som anser de kapitalistiske produktionsformer for at være absolute - for at være evige naturformer for produktionen - kan forvexle spørgsmålet om, hvad produktivt arbejde er fra kapitalens synspunkt, med spørgsmålet om, hvilket arbejde, der overhovedet er produktivt, eller hvad produktivt arbejde overhovedet er, og indbilder sig derfor meget klogt, at ethvert arbejde, som overhovedet producerer noget, resulterer $i$ et eller andet, eo ipso er produktivt arbejde.

1) Kun det arbejde, som direkte forvandler sig til kapital, er produktivt arbejde; altså kun det arbejde, som afsætter den variable kapital (v) som variabel og derfor $=\mathrm{v}+\mathrm{x}$. Er den variable kapital $=v$, før den udvexles med arbejde, således at vi har ligningen $y=v$, så er det arbejde, som forvandler $\mathrm{v}$ til $\mathrm{v}+\mathrm{x}$ og $\mathrm{y}=\mathrm{v}$ til $\mathrm{y}^{\prime}=\mathrm{v}+\mathrm{x}$, produktivt arbejde. Dette er et punkt, som bør udvikles. Arbejde, som skaber merværdi eller tjener som drivkraft for kapitalen til at skabe merværdi, og som derved bliver til kapital, til værdi, som yngler.

2) Arbejdets samfundsmæssige og almene produktivkræfter er kapitalens produktivkræfter, men disse produktivkræfter angår kun arbejdsprocessen eller berører kun brugsværdien. De udgør egenskaber, som tilkommer kapitalen som ting, som dens brugsværdi. De berører ikke umiddelbart bytteværdien. Om 100 personer arbejder sammen eller hver for sig: værdien af deres produkt $=100$ arbejdsdage, uanset om den realiseres $i$ mange eller få produkter, d.v.s. arbejdets produktivitet er uden betydning $i$ denne sammenhæng.

Kun på én måde er forskelle i arbejdets produktivitet af betydning for bytteværdien. 
Udvikler arbejdets produktivitet sig f.eks. i en enkelt produktionsgern - bliver der f.eks. undtagelsesvis vævet den samme mængde stof med en mekanisk væv som med en håndvæv, og kræver vævningen af en alen med den mekaniske væv kun halvdelen af den arbejdstid, som håndvævningen kræver, så realiseres 12 arbejds timer $i$ det sidste tilfælde ikke mere $i$ en værdi svarende til 12 timer, men $i$ en værdi svarende til 6, da den nødvendige arbejdstid nu er 6 timer. Håndvæverens 12 arbejdstimer er kun $=6$ timers samfundsmæssigt arbejde, skønt han som før arbejder 12 timer.

Men det er der ikke tale om her. Tag derimod en anden produktionsgren, f.ex. typografien, hvor der endnu ikke anvendes maskiner; her producerer 12 arbejdstimer lige så megen værdi som 12 arbejdstimer $i$ produktionsgrene, hvor maskineri etc. er udviklet til det yderste. Det værdiproducerende arbejde forbliver den enkeltes arbejde, men dette arbejde får et alment udtryk. Det produktive arbejde - som værdiproducerende arbejde - konfronterer derfor stedse kapitalen som den enkelte arbejdskrafts og den isolerede arbejders arbejde, i hvilken samfundsmæssig kombination denne arbejder end måtte indgå $i$ produktionsprocessen. Mens således kapitalen konfronterer arbejderen som arbejdets samfundsmæssige produktivkraft, konfronterer det produktive arbejde altid kun kapitalen som den isolerede arbejders arbejde.

3) Da det synes at være en naturegenskab for kapitalen - en egenskab af dens brugsværdi - at den tiltvinger sig merarbejde og tilriver sig arbejdets samfundsmæssige produktivkræfter, synes det omvendt at være en naturegenskab for arbejdet, at dets egne samfundsmæssige produktivkræfter bliver kapitalens produktivkræfter og dets eget merprodukt kapitalens selvrealisation.

For nu at udvikle disse 3 punkter og deraf udlede forskellen på produktivt og uproduktivt arbejde.

ad 1) Kapitalens produktivitet består $i$ at sætte arbejdet som lønarbejde op overfor arbejdets produktivitet og arbejdsredskaberne som kapital.
Vi har set, at penge forvandles til kapital, d.v.s. til en bestemt bytteværdi, som selv skaber værdi, forvandles til værdi + merværdi derigennem, at én del af værdien omsættes i sådanne varer, som tjener som arbejdsredskaber (råstof, instrumenter, kort sagt de objektive arbejdsbetingelser), mens en anden del anvendes til køb af arbejdskraft. Det er dog ikke denne første udvexling af penge og arbejdskraft - købet af arbejdskraft - som forvandler penge til kapital. Ved dette $k \varnothing b$ inkorporeres arbejdskraftens brug $i$ et bestemt tidsrum i kapitalen, og et bestemt kvantum levende arbejde gøres til en existensform for kapitalen, så at sige til dens livsprincip.

I den virkelige produktionsproces forvandles det levende arbejde til kapital, idet det på den ene side reproducerer arbejdslønnen - altså værdien af den variable kapital - og på den anden side afsætter merværdi, og gennem denne proces forvandles hele pengesummen til kapital, skønt kun den del, som er udlagt $i$ arbejdsløn, umiddelbart varierer. Var værdien før $=\mathrm{k}+\mathrm{v}$, så er den $\mathrm{nu}=\mathrm{k}+(\mathrm{v}+\mathrm{x})$, d. v. s.: den oprindelige pengesum, værdimængde, har ynglet, er på samme tid blevet bevaret og forøget.

(Den omstændighed, at forøgelsen kun skabes af den variable del af kapitalen, ændrer absolut intet ved, at den oprindelige samlede værdi synes at have ynglet, at være blevet forøget med merværdi, at altså den oprindelige samlede pengesum er blevet forvandlet til kapital. For den oprindelige værdi $=\mathrm{k}+\mathrm{v}$ (konstant og variabel kapital). I produktionsprocessen bliver den $=\mathrm{k}+(\mathrm{v}+\mathrm{x})$; sidstnævnte er den reproducerede del, som fremkommer gennem forvandlingen af levende arbejde til objektiveret arbejde, en forvandling, som betinges og indledes af udvexlingen af $\mathrm{v}$ mod arbejdskraft, af $\mathrm{v}^{\prime} \mathrm{s}$ forvandling til løn. Men $\mathrm{k}+$ $(\mathrm{v}+\mathrm{x})=\mathrm{k}+\mathrm{v}$ (den oprindelige kapital) $+x$. Desuden kan forvandlingen af $\mathrm{v}$ til $\mathrm{v}+\mathrm{x}-$ altså af $\mathrm{k}+\mathrm{v}$ til $(\mathrm{k}+$ $v)+x-$ kun ske $i$ kraft af, at en del af pengene forvandles til k. En del kan kun forvandles til variabel kapital, dersom en anden del forvandles til konstant kapital.) 
I den virkelige produktionsproces forvandler arbejdet sig rent faktisk til kapital, men denne forvandling betinges af den oprindelige udvexling af penge og arbejdskraft. Først $i$ kraft af denne umiddelbare forvandling af arbejde til obejktiveret arbejde, som ikke tilhører arbejderen, men kapitalisten, bliver pengene forvandlet til kapital, også den del, som har antaget form af produktionsmidler, arbejdsbetingelser. Før denne forvandling er pengene, hvad enten de existerer $i$ deres egen form eller $i$ form af varer (produkter), som har en sådan skikkelse, at de kan tjene som produktionsmidler for nye varer, kun kapital i sig selv (an sich).

Først denne bestemte relation til arbejdet forvandler penge eller varer til kapital; og det arbejde, som gennem sit forhold til produktionsbetingelserne - til hvilke der svarer bestemte relationer $i$ den virkelige produktionsproces - forvandler penge eller varer til kapital, d.v.s. det arbejde, som bevarer og forøger værdien af det selvstændiggjorte og objektiverede arbejde, som konfronterer arbejdskraften, er produktivt arbejde. Produktivt arbejde er blot et forkortet udtryk for hele denne relation og for måden, hvorpå arbejdskraften optræder i den kapitalistiske produktionsproces. Forskellen fra andre arter af arbejde er imidlertid af højeste vigtighed, da netop den udtrykker den formbestemthed af arbejdet, hvorpå den samlede kapitalistiske produktionsmåde og kapitalen selv beror.

Produktivt arbejde er altså $i$ det kapitalistiske produktionssystem - det arbejde, som producerer merværdi for arbejdsgiveren, eller som forvandler de objektive arbejdsbetingelser til kapital og deres ejer til kapitalist - altså arbejde, som producerer sit eget produkt som kapital.

Taler vi altså om produktivt arbejde, så taler vi om samfundsmæssigt bestemt arbejde, arbejde, som omfatter en ganske bestemt relation mellem køber og sælger af arbejde.

Skønt nu de penge - eller varer: i form af produktionsmidler og levneds- midler for arbejderen - som køberen af arbejdskraft er $i$ besiddelse af, først forvandles til kapital gennem produktionsprocessen, og skønt derfor disse ting - før de indgår i denne proces - ikke er kapital, men først skal blive til kapital, så er de dog i sig selv kapital: de er det i kraft af den selvstændige skikkelse, $i$ hvilken de konfronterer arbejdskraften, et forhold, som deres udvexling med arbejdskraften og den derpå følgende virkelige forvandling af arbejde til kapital betinger og sikrer. De har fra begyndelsen den samfundsmæssige bestemthed overfor arbejderen, som gør dem til kapital, og som giver dem ret til at bestemme over arbejdet. De er derfor - i modsætning til arbejdet - forudsat som kapital.

Produktivt arbejde kan derfor betegnes som det arbejde, som direkte udvexles mod penge som kapital, eller, hvad der blot er et kort udtryk for det samme, som umiddelbart udvexles mod kapital, d.v.s. mod penge, som i sig selv er kapital, som har den bestemthed at fungere som kapital, eller optræder overfor arbejderen som kapital. I udtrykket: arbejde, som umiddelbart udvexles mod kapital, ligger, at arbejdet udvexles mod penge som kapital og virkelig forvandler dem til kapital. Hvad der menes med: umiddelbart, vil fremgå af det følgende.

Produktivt arbejde er altså det arbejde, som for arbejderen kun reproducerer den $i$ forvejen bestemte værdi af hans arbejdskraft, men som derimod for kapitalen er en værdiskabende aktivitet, hvorigennem arbejderen konfronteres med den vær - di, han selv har skabt, $i$ form af kapital.

C) TO VASENSFORSKELLIGE TREK VED UDVEKSLINGEN AF KAPITAL OG ARBEJDE.

Ved udvexlingen af kapital og arbejde må man - som det fremgik af vore undersøgelser af produktionsprocessen skelne mellem to forskellige skønt hinanden betingende forhold.

1) Den første udvexling af arbejde og kapital er en formel proces, hvori kapitalen figurerer som penge og ar- 
bejdskraften som vare. Salget af arbejdskraften finder $i$ ideel eller juridisk forstand sted $i$ denne første proces, skønt arbejdet først betales efter udførelsen (efter en dag, en uge o.s.v.). Dette sidste ændrer dog intet ved selve transaktionen: salget af arbejdskraften. Det, som her umiddelbart sælges, er ikke en vare, hvori arbejdet allerede er realiseret, men selve brugen af arbejdskraften, altså faktisk arbejdet selv, da arbejdskraftens brug er dens virksomhed, er arbejde. Udvexlingen af arbejde formidles her ikke af en udvexling af varer. Når A sælger støvler til B, så udvexler de begge arbejde realiseret $i$ henholdsvis støvler og penge. Men her udvexles objektiveret arbejde $i$ sin almene samfundsmæssige form, d.v.s. som penge, mod det endnu kun som arbejdskraft existerende arbejde, og det, som sælges og købes, er brugen af denne kraft, altså arbejdet selv, skønt værdien af den solgte vare ikke er værdien af arbejdet (et irrationelt udtryk), men værdien af arbejdskraften. Der finder altså umiddelbart en udveksling sted mellem objektiveret arbejde og arbejdskraft, som de facto opløser sig i levende arbejde, altså mellem objektiveret arbejde og levende arbejde. Lønnen - arbejdskraftens værdi - fremtræder derfor, som vist tidligere, som den umiddelbare købspris, som prisen på arbejde.

I dette første moment er relationen mellem arbejder og kapitalist en relation mellem køber og sælger af en vare. Kapitalisten betaler værdien af arbejdskraften, altså værdien af den vare, som han køber.

Samtidig bliver arbejdskraften imidlertid kun købt, fordi den kan yde og forpligter sig til at yde mere arbejde end det, som er nødvendigt for arbejdskraftens reproduktion; arbejde, som derfor repræsenterer en større værdi end arbejdskraftens værdi.

2 ) Det andet moment i udvexlingen af kapital og arbejde har intet med det første at gøre, er strengt taget slet ingen udvexling.

I det første moment finder en udvexling af penge og vare sted, og arbej- der og kapitalist optræder her som ejere af varer. Der udvexles ækvivalenter. (d.v.s. det ændrer intet ved forholdet, hvornår de udvexles, eller om prisen på arbejdet er under eller over eller lig med arbejdskraftens værdi. Transaktionen kan altså finde sted i overensstemmelse med den almindelige lov for vareudvexling).

I det andet moment finder der slet ingen udvexling sted. Ejeren af penge er ophørt med at være køber af vare og arbejderen med at være sælger af vare. Ejeren af penge fungerer nu som kapitalist. Han konsumerer den vare, som han har købt, og arbejderen leverer den, da brugen af hans arbejdskraft er selve arbejdet. Ved den tidligere transaktion er arbejdet selv blevet en del af den objektiverede rigdom. Arbejderen udfører det, men det tilhører kapitalen og er kun en funktion af denne. Det sker derfor direkte under dens kontrol og direktion, og det produkt, hvori det objektiveres, er den nye form, hvori kapitalen viser sig, eller den snarere virkeliggøres som kapital. I denne proces objektiveres arbejdet derfor direkte, forvandles umiddelbart til kapital, idet det allerede formelt gennem den første transaktion er inkorporeret i kapitalen. Og rigtignok forvandles mere arbejde her til kapital, end købet af arbejdskraften kostede kapitalen. Kapitalen absorberer $i$ denne proces en del ubetalt arbejde, og kun derved forvandles penge til kapital.

Skønt der her i virkeligheden ikke forekommer nogen udvexling - bortset fra formidlingen - er resultatet af processen - begge momenter under ét at et bestemt kvantum objektiveret arbejde er blevet udvexlet med et større kvantum levende arbejde, d.v.s. der er blevet objektiveret mere arbejde end arbejdskraften repræsenterer og derfor mere end den mængde objektiveret arbejde, som virkelig bliver udbetalt til arbejderen, og kapitalisten får ikke blot den del af kapitalen, som han har udbetalt i arbejdsløn, tilbage, men han får også en merværdi, som ikke koster ham noget. Den umiddelbare udvexling af arbejde mod kapital betyder her 1) den umiddelbare forvandling af arbejde til kapital, til en 
objektiveret bestanddel af kapitalen i produktionsprocessen, 2) udvexlingen af et bestemt kvantum objektiveret arbejde mod det samme kvantum levende arbejde plus et merkvantum levende arbejde, som tilegnes uden udvexling.

Det udtryk, at produktivt arbejde er arbejde, som udvexles umiddelbart med kapital, omfatter alle disse forhold og er blot en anden formulering af, at det er arbejde, som forvandler penge til kapital, som udvexles med produktionsbetingelserne som kapital, og som altså ikke på nogen måde forholder sig til dem som til enkle produktionsbetingelser, som arbejde slet og ret, men som forholder sig til dem som specifikt, socialt bestemt arbejde.

Det omfatter dette: 1) pengenes forhold til arbejdskraften som én vares forhold til en anden, købet og salget mellem pengenes ejer og ejeren af arbejdskraften, 2) arbejdets direkte underkastelse under kapitalen, 3) arbejdets faktiske forvandling til kapital i produktionsprocessen, eller - udtrykt andeledes - skabelsen af merværdi for kapitalen. Der finder to udvexlinger sted mellem arbejde og kapital. Den første udtrykker blot købet af arbejdskraften og derfor af arbejdet og derfor af dets produkt. Den anden udtrykker den direkte forvandling af levende arbejde til kapital og dets objektivering som kapitalens realisering.

\section{D) DET PRODUKTIVE ARBEJDES SPECI- FIKKE BRUGSVERDI FOR KAPITALEN.}

Resultatet af den kapitalistiske produktionsproces er hverken blot et produkt, en brugsværdi, eller en vare, d.v.s. en brugsværdi, som har en bestemt bytteværdi. Dens resultat, dens produkt er skabelsen af merværdi for kapitalen og derved den faktiske forvandling af penge eller varer til kapital, hvilket forud for produktionsprocessen blot var deres intention, deres bestemmelse. I produktionsprocessen absorberes mere arbejde, end der købes, og denne tilegnelse af fremmed ubetalt arbejde, som fuldbringes i produktionsprocessen, er det umiddelbare mål for den kapitalistiske produktionsproces; for det, som kapitalen som kapital (og derfor kapita- listen som kapitalist) vil producere, er hverken umiddelbare brugsværdier for sin egen konsumtion eller varer, som den kan forvandle først til penge og derpå til brugsværdi. Dens mål er berigelsen, forøgelsen af værdier, at bevare de gamle værdier og at skabe merværdi. Og dette særlige produkt af den kapitalistiske produktionsproces fremkommer kun ved en udvexling med arbejde; arbejde, som af den grund hedder produktivt arbejde.

Arbejdet - derved at det producerer en vare - må være nyttigt arbejde, producere en brugsværdi, manifestere sig $i$ en brugsværdi. Og derfor udvexles kapital kun med arbejde, som konkretiseres $i$ en vare, altså i brugsværdi. Dette er en selvfølgelig forudsætning. Men det er ikke arbejdets konkrete karakter, dets brugsværdi som sådan, som f.ex. skrædderarbejde, skomagerarbejde, spindeeller vævearbejde, som danner dets specielle brugsværdi for kapitalen, og som derved stempler det som produktivt arbejde $i$ det kapitalistiske produktionssystem. Det, som danner arbejdets specifikke brugsværdi for kapitalen, er ikke dets bestemte, nyttige karakter, ligesålidt som det er de særlige, nyttige egenskaber hos de produkter, hvori det objektiveres. Men det er derimod dets evne - i sin egenskab af abstrakt arbejde - til at skabe bytteværdi; rigtignok ikke, at det overhovedet repræsenterer et bestemt kvantum af dette almene arbejde, men at det repræsenterer et større kvantum end det, som indgår i prisen på arbejdet d.v.s. end det, som er indeholdt $i$ arbejdskraftens værdi.

Arbejdskraftens brugsværdi for kapitalen udtrykkes netop af, at det kvantum arbejde, som den præsterer, er større end det kvantum, som er objektiveret i arbejdskraften selv, som er nødvendigt for dens reproduktion. Den præsterer naturligvis dette kvantum arbejde $i$ den bestemte form, som tilkommer det som særegent nyttigt arbejde. Men arbejdets konkrete karakter - som overhovedet sætter det $i$ stand til at manifestere sig i en vare - er ikke dets specifikke brugsværdi for kapitalen. Brugsværdien for kapitalen består $i$, at det overhove- 
det er arbejde, og får sit udtryk i differencen mellem det arbejdskvantum, arbejdet yder, og det, som det koster.

En bestemt pengesum $\mathrm{p}$ bliver kapital derved, at den $i$ produktet realiseres som $\mathrm{p}+\mathrm{x}, \mathrm{d} \cdot \mathrm{v} . \mathrm{s}$. at det kvantum arbejde, den indeholder som produkt, er større end det kvantum arbejde, den oprindelig indeholdt. Og dette er resultatet af udvexlingen af penge og produktivt arbejde, eller: kun det arbejde er produktivt, som, idet det udvexles med objektiveret arbejde, sætter dette sidste $i$ stand til at blive til en forøget mængde objektiveret arbejde.

Den kapitalistiske produktionsproces er derfor ikke blot produktion af varer. Det er en proces, som absorberer ubetalt arbejde, og som gør materialer og arbejdsredskaber - produktionsmidlerne - til midler for absorberingen af ubetalt arbejde.

Af det foregående fremgår, at karakteriseringen af arbejdet som produktivt næsten intet har at gøre med arbejdets bestemte indhold, dets særlige nytte eller med den specielle brugsværdi, hvori det realiseres.

Det samme slags arbejde kan være produktivt eller uproduktivt.

F.ex. var Milton, som skrev "Paradise Lost" for $5 \mathrm{E}$, en uproduktiv arbejder. Den forfatter, derimod, som yder fabriksarbejde for en boghandler, er en produktiv arbejder. Milton producerede "Paradise Lost" af samme grund, som en silkeorm producerer silke. Det var hans naturlige virksomhed. Han solgte senere produktet for $5 \mathrm{E}$. Men den litteraturproletar i Leipzig, som producerer bøger (eller kompendier om økonomi) under direktion af en boghandler, er en produktiv arbejder, for hans produkt er på forhånd underlagt kapitalen og fremstilles udelukkende med kapitalens forøgelse for øje. En sangerinde, som på egen hånd sælger sin sang, er en uproduktiv arbejder. Men den samme sangerinde, som er engageret af en impressario, der tjener penge på at lade hende synge, er en produktiv arbejder, fordi hun producerer kapital.
E) UPRODUKTIVT ARBEJdE SOM TJENE-

STEYDENDE ARBEJDE .

$K \emptyset B$ AF TJENESTEYDELSER UNDER

KAPITALISMENS BETINGELSER .

DEN VULGARE OPFATTELSE AF

FORHOLDET MELLEM KAPITAL OG

ARBEJDE SOM EN UDVEXLING AF

TJENESTEYDELSER .

Man må her skelne mellem forskellige spørgsmål.

Om jeg køber et par bukser, eller jeg køber stof og tager en skræddersvend $i$ huset, som jeg betaler for hans tjeneste (hans skrædderarbejde): forvandlingen af stoffet til bukser, er fuldstændig ligegyldigt for $\mathrm{mig}$, så vidt det kun drejer sig om bukserne. Når jeg benytter den førstnævnte fremgangsmåde, er det fordi det er den billigste, idet bukserne koster mindst arbejde, når de produceres af manufakturindustrien. Men $i$ begge tilfælde forvandler jeg de penge, som jeg køber bukser for, til bukser og ikke til kapital, og i begge tilfælde drejer det sig for mig om at anvende pengene som blot og bart cirkulationsmiddel, d.v.s. om at forvandle dem til denne bestemte brugsværdi. Her fungerer pengene ikke som kapital, skønt de $i$ det ene tilfælde byttes med en vare, $i$ det andet køber selve arbejdet som vare. De fungerer kun som penge og mere bestemt som cirkulationsmiddel.

På den anden side er skræddersvenden ikke nogen produktiv arbejder, skønt hans arbejde leverer mig produktet (bukserne) og ham selv prisen på hans arbejde (pengene). Det er muligt, at det kvantum arbejde, som svenden præsterer, er større end det, som er indeholdt $i$ den pris, jeg betaler ham. Og det er endog sandsynligt, da prisen på hans arbejde bestemmes af prisen på de produktive skræddersvendes arbejde. Men dette er fuldstændig uden betydning, hvad mig angår. Om han arbejder 8 eller 10 timer, efter at prisen er fastsat, er mig ganske ligegyldigt. Det drejer sig blot om brugsværdien, bukserne, idet jeg dog naturligvis, hvad enten jeg køber dem på den ene eller den anden måde, ønsker at betale så lidt som muligt for dem og hverken mere eller mindre $i$ det ene tilfælde end $i$ det andet, 
men deres normalpris. Det er en udgift med henblik på konsumtion; det er ikke en forøgelse, men en formindskelse af mine penge. Det er overhovedet ikke et middel til berigelse ligesålidt som enhver anden udgift til personligt forbrug.

En af Paul de Kock's lærde vil måske fortælle mig, at jeg uden dette køb - og uden at købe brød - ikke kan leve og altså ikke berige mig, og at det derfor er et indirekte middel eller $i$ det mindste en betingelse for min berigelse. På samme måde som mit blodomløb og mit åndedræt er betingelsen for min berigelse. Men $i$ og for sig beriges jeg hverken af mit blodomløb eller af mit åndedræt; begge forudsætter tværtimod et kostbart stofskifte, og hvis dette ikke var en nødvendighed fandtes der ingen fattige djævle. En blot og bar udvexling af penge og arbejde forvandler ikke derved pengene til kapital eller arbejdet til produktivt arbejde.

Hvad er nu karakteristisk for denne udvexling? Hvorved adskiller den sig fra udvexlingen af penge mod produktivt arbejde? På den ene side derved, at pengene gives ud som penge, som en selvstændig form for bytteværdi, som skal forvandles til brugsværdi, til levnedsmidler, til genstande for personlig konsumtion. Pengene bliver altså ikke til kapital, men mister tværtimod deres existens som bytteværdi for at blive forbrugt som brugsværdi, for at blive fortæret. På den anden side har arbejdet blot interesse for mig som brugsværdi, som en tjeneste, der forvandler stoffet til bukser, og hvis bestemte nyttige karakter kommer mig til gode.

Derimod består den tjeneste, som den samme skræddersvend - når han er ansat i manufakturindustrien - yder kapitalisten på ingen måde deri, at han forvandler stof til bukser, men deri, at den nødvendige arbejdstid, som er realiseret $i$ et par bukser, er 12 arbejdstimer, og den løn, svenden får, svarer til 6 timer. Den tjeneste, som han har ydet, består altså deri, at han arbejder 6 timer gratis. At dette sker $i$ form af tilvirkning af bukser skjuler kun det virkelige forhold. Så snart der er mulighed for det, søger kapitalisten derfor igen at forvandle bukserne til penge, d.v.s. til en form, i hvilken skrædderarbejdets bestemte karakter ganske er forsvundet, og hvori den ydede tjeneste kommer således til udtryk, at i stedet for en arbejdstid på 6 timer, hvortil der svarer en bestemt sum penge, er 12 timers arbejdstid for hånden, hvortil den dobbelte sum penge svarer.

Jeg køber skrædderarbejdet på grund af de tjenester, det yder som skrædderarbejde, for at tilfredsstille mit behov for klæder, for at tilfredsstille et af mine behov. Kapitalisten køber skrædderarbejdet som et middel til at gøre 1 daler til 2 . Jeg køber det, fordi det producerer en bestemt brugsværdi, yder en bestemt tjeneste, kapitalisten køber det, fordi det præsterer mere bytteværdi end det koster, som et blot og bart middel til at udvexle mindre arbejde med mere.

Hvor udvexlingen af penge og arbejde finder sted direkte, uden at sidstnævnte producerer kapital, altså ikke er produktivt arbejde, bliver arbejdet købt som tjenesteydelse; dette er blot et udtryk for den særegne brugsværdi, arbejdet har ligesom enhver anden vare, men et specifikt udtryk for denne særegne brugsværdi, som består $i$, at tjenesten ikke ydes som ting, men som virksomhed, hvilket dog på ingen måde adskiller den fra f.ex. en maskine: f.ex. et ur. Do ut facias, facio ut facias, facio ut des, do ut des ${ }^{1)}$ er her forskellige former for det samme forhold, mens $i$ den kapitalistiske produktion do ut facias er udtryk for et specielt forhold mellem den objektiverede værdi, som er givet, og den levende virksomhed, som opsuges. Det specifikke forhold mellem arbejde og kapital er slet ikke indeholdt $i$ købet af tjenesteydelser, det er enten helt opløst eller existerer slet ikke. Derfor er det naturligvis den form, som Say, Bastiat og co. med forkærlighed be-

1) udtryk fra romerretten: "ich gebe, damit du tust, ich tue, damit du tust, ich tue, damit du gibst, ich gebe, damit du gibst". 
nytter for at udtrykke forholdet mellem kapital og arbejde. ${ }^{2)}$

Det fremgår, at en blot og bar udvexling af penge og arbejde ikke forvandler sidstnævnte til produktivt arbejde, og at indholdet af dette arbejde næsten er ligegyldigt.

Arbejderen kan selv købe arbejde varer $i$ form af tjenesteydelser - for sin løn, og dette køb adskiller sig overhovedet ikke fra købet af en hvilkensomhelst anden vare. De tjenesteydelser, han køber, kan være mere eller mindre nødvendige: som lægens eller præstens tjenesteydelser, ganske som han kan købe brød eller snaps. Som køber - som repræsentant for penge $i$ relation til en vare - befinder arbejderen sig helt $i$ den samme kategori som kapitalisten, når denne kun optræder som køber, d.v.s. hvor det kun drejer sig om at omsætte penge til varer.

Idet således en blot og bar udvexling af penge og arbejde ikke forvandler sidstnævnte til produktivt arbejde eller - hvad der er det samme - ikke førstnævnte til kapital, så viser arbejdets indhold, dets konkrete karakter, dets specifikke nyttighed, sig også at være næsten uden betydning: vi har netop set, at skræddersvendens arbejde er produktivt arbejde $i$ det ene tilfælde, men ikke $i$ det andet.

Visse tjenesteydelser eller brugsværdier, produkter af bestemte former for virksomhed eller arbejde, manifesterer sig i varer, andre derimod efterlader intet håndgribeligt og fra personen selv forskelligt resultat, eller deres resultat er ingen salgbar vare. F.ex. tilfredsstiller den tjeneste, som en sanger yder, mit æstetiske behov, men det, som jeg nyder, eksisterer uadskilleligt fra sangeren selv, og så snart hans arbejde (sangen) er forbi, er min nydelse til ende: jeg nyder virksomheden selv: dens virkning på mit øre. Tjenesteydelserne kan - li-

2) Hvordan prisen på disse tjenester bestemmes, $i$ hvor høj grad den reguleres af lovene for den egentlige arbejdsløn, og $i$ hvor høj grad den ikke gør det, er spørgsmål, som må behandles $i$ en afhandling om arbejdsløn, og som er ganske uden betydning for den aktuelle undersøgelse. gesom varer - være nødvendige eller blot synes nødvendige, som f.ex. en soldats, eller en læges, eller en advokats tjeneste, eller de kan være tjenester, som bibringer mig nydelse. Dette ændrer intet ved deres økonomiske bestemthed. Når jeg er rask og ikke har brug for lægen, eller har det held ikke at behøve at føre processer, så skyr jeg som pesten at bruge penge på lægens eller juristens tjenester.

Tjenesteydelserne kan også være én påtvungne, som embedsmændenes tjenesteydelser etc.

Når jeg køber en lærers tjeneste, ikke for at udvikle mine evner, men for at erhverve mig færdigheder, ved hvis hjælp jeg kan tjene penge, eller hvis andre køber denne lærer for mig, og når jeg virkelig lærer noget, hvilket $i$ og for sig ikke kommer betalingen af tjenesteydelsen ved, så tilhører disse læreomkostninger - ganske som midlerne til mit underhold - min arbejdskrafts produktionsomkostninger. Men disse tjenesteydelsers specifikke nytte ændrer intet ved det økonomiske forhold; jeg forvandler ikke penge til kapital, ej heller forvandler læreren, som forretter tjenesten, mig til sin kapitalist, sin herre. Det er derfor også ganske ligegyldigt for disse forholds økonomiske bestemthed om lægen kurerer mig, om læreren opnår resultater i sin undervisning, om advokaten vinder sin proces. Det, der betales for, er tjenesteydelsen som sådan, hvis resultat er af en sådan beskaffenhed, at de tjenesteydende ikke kan give nogen garanti. En stor del af tjenesteydelserne er konsumtionsomkostninger for varer: kokkepige, tjenestepige, etc..

Det er karakteristisk for alt uproduktivt arbejde, at det - som alle andre konsumtionsvarer - kun står til disposition $i$ samme forhold som det produktive arbejde udbyttes. Af alle personer har den produktive arbejder derfor mindst rådighed over uproduktive arbejderes tjenesteydelser, skønt han må betale mest for de ufrivillige tjenesteydelser (stat, skat). Men omvendt voxer min magt til at anvende produktive arbejdere ikke i takt med anvendelsen af uproduktive arbejdere, den aftager tværtimod $i$ det samme forhold. 
Selv de produktive arbejdere kan - i deres forhold til mig - være uproduktive arbejdere. F.ex. hvis jeg lader mit hus tapetsere, og tapetsererne er lønarbejdere for en mester, som sælger mig udførelsen af denne opgave, så er det for mig det samme, som hvis jeg havde købt et færdigtapetseret hus, havde givet mine penge ud på en vare til mit forbrug, men for mesteren, som lader disse arbejdere tapetsere, er de produktive, for de producerer merværdi til ham. ${ }^{3)}$

Kapitalens produktionsproces. Vi har set: produktionsprocessen er ikke kun produktion af varer, men produktion af merværdi, absorbering af merarbejde og derfor den proces, i hvilken kapitalen produceres. Den første formelle udvexling af penge og arbejde eller kapital og arbejde udgør kun selve muligheden for tilegnelsen af fremmed, levende arbejde ved hjælp af objektiveret arbejde. Den virkelige tilegnelse foregår først $i$ den virkelige produktionsproces, som har ladt den første formelle transaktion - hvor kapitalisten og arbejderen blot konfronterer hinanden som indehavere af varer, blot forholder sig til hinanden som køber og sælger - bag sig. Alle vulgærøkonomer bliver stående ved den første formelle transaktion, netop for at bortsvindle dette specifikke forhold. I udvexlingen af penge og uproduktivt arbejde viser forskellen mellem de to stadier sig slående. Her udvexles penge og arbejde kun som varer. Denne udvexling skaber

3) I hvor høj grad den arbejder, som ganske vist producerer en salgbar vare, men en vare, som indbringer ham et beløb svarende til værdien af hans arbejdskraft - hvorfor han altså ikke producerer merværdi for kapitalen ikke er produktiv set fra den kapitalistiske produktions synspunkt, ser man allerede hos Ricardo: " the very existence of such people is a nuisance". (Ricardo: Principles of political economy and taxation, London 1819). Dette er kapitalens teori og praksis. "Both the Theory relative to capital, and the practice of stopping labour at that point where it can produce, in addition to the subsistence of the labourer, a profit for the capitalist seem opposed to the natural laws which regulate production." (Th. Hodgskin: Popular Political Economy, London 1827). ikke kapital, den udtrykker tværtimod et forbrug af indtægt.

\section{F) HÅNDVERKERENS OG BONDENS ARBEJDE I DET KAPITALISTISKE SAMFUND.}

Hvordan forholder det sig nu med selvstændige håndværkere eller bønder, som ikke beskæftiger arbejdere, altså ikke producerer som kapitalister? De er vareproducenter og jeg køber varer af dem (det gælder altid bonden, men ikke f.ex. den gartner, jeg tager i mit hus); dette forhold ændres ikke af, at håndværkeren leverer på bestilling, eller af, at bondens udbud afhænger af mængden af hans midler. De optræder her overfor mig som sælgere af varer, ikke som sælgere af arbejde; dette forhold har altså intet at gøre med udvexling af arbejde og kapital og altså heller ikke med forskellen mellem produktivt og uproduktivt arbejde, som blot beror på, om arbejdet udvexles med penge som penge eller med penge som kapital. De tilhører derfor hverken de produktive eller de uproduktive arbejderes kategori; ganske vist producerer de varer, men deres produktion er ikke underordnet den kapitalistiske produktionsmåde.

Det er muligt, at disse producenter, som arbejder med deres egne produktionsmidler, ikke blot reproducerer arbejdskraften, men også skaber merværdi, idet deres stilling tillader dem at tilegne sig deres egen merværdi eller en del af den (en anden del tages fra dem $i$ form af skat etc.). Og her støder vi på en ejendommelighed, som er karakteristisk for et samfund, i hvilket en bestemt produktionsmåde er fremherskende, skønt ikke alle produktionsforhold er underkastet denne. I det feudale samfund f.ex. - som man bedst kan studere det i England, idet feudalismen her blev indført fra Normandiet $i$ sin færdige udformning og denne form påtrykt et $i$ mange henseender forskelligt samfundsunderlag bevarede relationerne også et feudalt udtryk, som står feudalismens væsen fjernt, f.ex. blotte pecuniære relationer, hvor det på ingen måde drejer sig om overhøjhedens og vasallens gensidige personlige tjenester. F.ex. fiktionen, at den lille bonde har sin ejendom som len. 
Ligesådan mht. den kapitalistiske produktionsmåde. Den uafhængige bonde eller håndværker spaltes $i$ to personer. ${ }^{4}$

Som ejer af produktionsmidlerne er han kapitalist, som arbejder er han sin egen lønarbejder. Som kapitalist udbetaler han sig selv løn og opnår profit af sin kapital, d.v.s. han udbytter sig selv som lønarbejder og modtager - $i$ form af merværdien - den tribut, som arbejdet skylder kapitalen. Måske betaler han også jordrente til sig selv i sin egenskab af jordejer, ganske som industrikapitalisten, når han anvender sin egen kapital, betaler sig selv rente og betragter dette som noget, han har krav på, ikke som industrikapitalist, men som kapitalist slet og ret.

Produktionsmidlernes samfundsmæssige bestemthed i den kapitalistiske produktion - som karakteriserer et bestemt produktionsforhold - er så sammenvoxet med, og $i$ det borgerlige samfunds egen opfattelse så uadskillelig fra, produktionsmidlernes materielle existens som produktionsmidler, at enhver (kategorisk) bestemthed også anvendes, hvor den direkte modsiger forholdene. Produktionsmidlerne bliver kun til kapital i den udstrækning, de er selvstændiggjort og konfronterer arbejdet som en selvstændig magt. I det givne tilfælde ejer producenten arbejderen - sine egne produktionsmidler. Disse er altså ikke kapital, ligesålidt som han optræder overfor dem som lønarbejder. Ikke desto mindre opfattes de som kapital, og producenten spaltes, således at han som kapitalist anvender sig selv som lønarbejder.

I virkeligheden er denne fremstillingsmåde - så irrationel den end kan synes ved første øjekast - korrekt så vidt: Producenten skaber ganske rigtigt $i$ det givne tilfælde sin egen merværdi (forudsat at varen sælges for dens værdi), eller kun hans eget arbejde objektiveres $i$ produktet. Men at han selv kan tilegne sig hele resultatet af sit eget arbejde, at en anden ikke tilegner

\footnotetext{
4) "I den mindre bedrift er indehaveren ofte sin egen arbejdskraft". (Storch: Cours d'économie politique, St. Petersborg, 1815).
}

sig forskellen mellem produktets værdi og gennemsnitsprisen på hans arbejde, det har han ikke sit eget arbejde at takke for - det adskiller ham ikke fra andre arbejdere - men derimod ejendomsretten til produktionsmidlerne. Det er altså kun i kraft af denne ejendomsret, at han kan bemægtige sig sit eget merarbejde, og således forholder han sig som sin egen kapitalist til sig selv som lønarbejder.

Adskillelsen optræder som det normale forhold i dette samfund, og hvor den altså faktisk ikke finder sted, forudsættes den alligevel, og dette er - som vist ovenfor - sådan set korrekt; for foreningen optræder her som noget tilfældigt, adskillelsen som det normale (i modsætning til gammelromerske eller norske tilstande eller de amerikanske i det nordvestlige USA), og adskillelsen fastholdes derfor, selv når de forskellige funktioner forenes $i$ én person. Det fremgår helt klart af dette, at kapitalisten som sådan kun er en funktion af kapitalen og arbejderen kun en funktion af arbejdskraften. Det er da også klart, at den økonomiske udvikling fordeler funktionerne på forskellige personer, og håndværkere og bønder, som producerer med egne produktionsmidler, vil efterhånden enten blive forvandlet til små kapitalister, idet også de begynder at udbytte fremmed arbejde, eller også mister de deres produktionsmidler (dette kan ske, skønt de vedbliver at være de nominelle ejere: hypotekvæsnet) og bliver lønarbejdere. Dette er tendensen $i$ den samfundsform hvori den kapitalistiske produktionsmåde er fremherskende.

\section{G) SEKUNDAR BESTEMMELSE AF DET PRO- DUKTIVE ARBEJDE SOM ARBEJDE, DER REALISERES I MATERIEL RIGDOM}

Ved en betragtning af den kapitalistiske produktions væsentligste relationer kan det altså tilføjes, at hele universet af varer, alle sfærer af den materielle produktion, al produktion af materiel rigdom, er underlagt den kapitalistiske produktionsmåde (formelt eller reelt) - idet tilnærmelsen hertil finder sted i stadig stigende grad, er det principielle mål, og idet arbejdets produktiv- 
kræfter kun herved udvikles i fuldt omfang. I denne forudsætning, som udtrykker grænsen, og som altså mere og mere korrekt beskriver virkeligheden, ligger, at alle de arbejdere, som er beskæftiget med produktion af varer, er lønarbejdere, og at de $i$ alle vareproduktionens sfærer konfronteres af produktionsmidlerne som kapital. Det kan betegnes som karakteristisk for de produktive arbejdere, d.v.s. for de arbejdere, som producerer kapital, at deres arbejde realiseres i varer, i materiel rigdom. Og således kan det produktive arbejde få en bibetydning, som er forskellig fra dets vigtigste karakteristikum, som ser bort fra arbejdets indhold og er uafhængigt af dette.

\section{H) KAPITALISMENS FREMTRADEN PÅ DEN IMMATERIELLE PRODUKTIONS OMRÅDE.}

Der er to muligheder med hensyn til den ikke-materielle produktion, selv når den sker udelukkende med henblik på udvexling, altså producerer varer:

1) At den resulterer i varer, brugsværdier, som besidder en fra producenten og konsumenten forskellig skikkelse, og som altså kan existere $i$ et interval mellem producent og konsument og cirkulere $i$ dette interval som salgbare varer, som $f$. ex. bøger, malerier, kort sagt alle kunstprodukter, som er forskellige fra den udøvende kunstners kunstpræstation. Her er kapitalistisk produktion kun $i$ begrænset omfang anvendelig, som når f.ex. en forfatter udbytter en mængde andre mennesker som håndlangere $i$ produktionen af et fælles værk, en encyklopædi f.ex. Men det bliver her for det meste ved en overgangsform til den kapitalistiske produktion, således at de forskellige producenter af videnskab eller kunst, håndværkere eller professionelle, arbejder for en boghandlers samfundsmæssige handelskapital, en relation, som intet har at gøre med den egentlige kapitalistiske produktionsmåde, og som endog formelt endnu ikke er underlagt denne. Det ændrer intet ved sagen, at det netop er i disse overgangsformer, den kraftigste udbytning af arbejdet finder sted.
2) at produktionen ikke kan adskilles fra produktionsakten, hvilket gælder alle udøvende kunstnere, talere, skuespillere, lærere, læger, præster etc. Også her finder den kapitalistiske produktionsmåde kun anvendelse $i$ begrænset omfang og - $i$ følge sagens natur- kun på nogle områder. F.ex. kan lærerne ved en læreanstalt være lønarbejdere for læreanstaltens arbejdsgiver. Skønt de ikke er produktive arbejdere overfor eleverne, kan de være det $i$ forhold til arbejdsgiveren. Han udvexler sin kapital mod deres arbejdskraft og beriger sig ved denne proces. Ligeså med foretagender som f.ex. teatre, forlystelsesetablissementer etc. Skuespilleren forholder sig her til publikum som kunstner, men overfor arbejdsgiveren er han en produktiv arbejder. De forskellige former for kapitalistisk produktion på dette område er $i$ den grad uden betydning sammenlignet med produktionen som helhed - at de ganske kan lades ude af betragtning.

\section{I) PRODUKTIVT ARBEJDE SET FRA DEN SAMLEDE MATERIELLE PRODUKTIONS- PROCES' SYNSPUNKT.}

Med udviklingen af den specifikke kapitalistiske produktionsmåde, hvor mange personer arbejder sammen i produktionen af den samme vare, må det forhold, hvori deres arbejde umiddelbart står til genstanden for produktionen, naturligvis være meget forskelligt fra den ene person til den anden. F.ex. har håndlangeren $i$ en fabrik ikke direkte at gøre med bearbejdelsen af råstoffer. Arbejderen, som står under direktion af den inspektør, der har med denne bearbejdelse at gøre, befinder sig $i$ en anden situation. Og forholdet er igen et andet for ingeniøren, som fortrinsvis arbejder med hovedet. Men den helhed, som disse arbejdere danber - og som består af nogenlunde éns mængder arbejdskraft af forskellig værdi - producerer det resultat, der konkretiseres som vare eller som materielt produkt; disse arbejdere udgør tilsammen en levende produktionsmaskine for dette produkt, ligesom de - idet vi nu betragter hele produktionsprocessen og ikke blot dens resultat - udvexler deres arbejde mod 
kapital og reproducerer kapitalistens penge som kapital, d.v.s. som værdi, der yngler, værdi, der forøges.

Det er netop det ejendommelige ved den kapitalistiske produktionsmåde, at den adskiller de forskellige former for arbejde, altså også åndsarbejde og legemligt arbejde - eller arbejde, hvor den ene eller den anden side er fremherskende - og fordeler dem på forskellige personer, hvilket dog ikke forhindrer, at det materielle produkt er disse personeres fælles produkt objektiveret $i$ materiel rigdom; hvilket på sin side ligesålidt hindrer eller ændrer noget ved, at hver enkelt af disse personer forholder sig som lønarbejder - som produktiv arbejder til kapitalen. Alle disse personer er ikke blot beskæftiget umiddelbart i produktionen af materiel rigdom, men de udvexler også umiddelbart deres arbejde mod penge som kapital og producerer derfor umiddelbart - foruden den værdi, som modsvarer deres løn - en merværdi, som tilfalder kapitalisten. Deres arbejde består af betalt og ubetalt arbejde.

\section{K) TRANSPORT INDUSTRIEN SOM DEL AF DEN MATERIELLE PRODUKTION. DET PRODUKTIVE ARBEJDE I TRANS - PORT INDUSTRIEN .}

Foruden den extraktive industri, landbruget og fabriksindustrien existerer der endnu en sfære $i$ den materielle produktion, som også gennemløber de forskellige stadier: håndværksdrift, drift som manufaktur og mekanisk drift, og det er lokomotionsindustrien: transporten af mennesker eller varer. Det produktive arbejdes - lønarbejdets - forhold til kapitalen er her ganske det samme som $i$ de andre sfærer af den materielle produktion. Endvidere sker der her en materiel forandring med arbejdets genstand: en rumlig forandring, en stedsforandring. Med hensyn til transporten af mennesker, forekommer denne blot at være en tjeneste, som ydes af driftsherren. Men forholdet mellem køber og sælger af disse tjenester har intet med den produktive arbejders forhold til kapital at gøre, ligesålidt som køber og sælger af twist har det.

Med hensyn til transporten af varer, så resulterer arbejdsprocessen her $i$ en ændring af arbejdsgenstanden, af varen. Den flyttes fra et sted til et andet, og derved ændres dens brugsværdi. Dens bytteværdi forøges med den sum arbejde, som ændringen af brugsværdien kræver; denne sum består dels af den del af det objektiverede arbejde, som indgår i varen - sliddet på den konstante kapital - dels af levende arbejde; analogt med alle andre varers realiseringsproces.

Så snart varen har nået sit bestemmelsessted, er ændringen af brugsværdien igen forsvundet og kommer blot til udtryk i varens forøgede bytteværdi, i dens fordyrelse. Skønt det reelle arbejde ikke har efterladt sig noget spor $i$ brugsværdien, er det alligevel realiseret $i$ dette materielle produkts bytteværdi; som $i$ enhver anden sfære af den materielle produktion legemliggøres arbejdet $i$ varen, skønt det i dette tilfælde ikke efterlader noget synligt spor $i$ varens brugsværdi.

Vi har her endnu kun at gøre med den produktive kapital, d.v.s. den kapital, som optræder $i$ den umiddelbare produktionsproces. Vi kommer senere til kapitalen i cirkulationsprocessen. Og først senere endnu vil vi studere den særegne skikkelse, som kapitalen antager som handelskapital, og først da kan der gives svar på spørgsmålet om, hvorvidt de arbejdere, som beskæftiges af kapitalen $i$ denne form, er produktive eller ej.

oversat fra:

KARL MARX: THEORIEN ÜBER DEN MEHRWERT TEIL I

MARX/ENGELS WERKE: BAND 26,1 (DIETZ VERLAG BERLIN 1965)

oversat af Sten Barfort. 


\title{
DAYSY. SOCIOLOGFORENIIIG
}

DANSK SOCIOLOGFORENING er en faglig forening og fagforening for yngre danske sociologer. Medlemsberettigede er kandidater og magistre, hvis hovedbeskæftigelse er af sociologisk art samt 2' dels sociologistuderende. Medlemsgebyr for kandidatmedlemmer $\mathrm{kr}$. 100,- for studentermedlemmer $\mathrm{kr}$. 30,- pr. år.

Foreningen arrangerer et årligt seminar, møder m.v. Desuden kan foreningens medlemmer deltage $i$ en Sociologisk Verdenskongres i Varna (Bulgarien) 14-19 sept. 1970 samt $i$ en Nordisk Sociologkongres i Åbo (Finland) 5-7 juni 1970. Endelig giver medlemsskab af DANSK SOCIOLOGFORENING adgang til at abonnere på Acta Sociologica med prisreduktion.

Yderligere oplysninger og indmeldelse hos foreningens kasserer:

Thomas Boje, Rektorparken 20.32450 København SV.

telefon 21.22 .67 lokal 85

\section{tysk \\ bogimport}

\author{
ADORNO - BENJAMIN - DAHRENDORF \\ HABERMAS - HORKHEIMER - LUKÁCS \\ MARCUSE
}

Oversættelser af engelske, franske mm. sociologer, der ikke er tilgængelige på originalsprogene.

\section{TYSK ER ET HOVEDSPROG FOR \\ SOCIOLOGISTUDERENDE}

Se på vor afdeling for sociologisk litteratur på tysk.

\section{TYSK BOGIMPORT A/S}

V. Voldgade 83, 1552 København V PA $6016 / 6097$
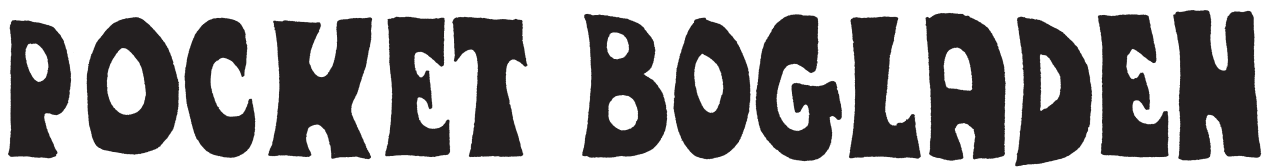

\section{EIOLSTREDE $32-1171 \mathrm{~K}-116042$}

\begin{abstract}
ALTHUSSER BARTES CARMICHAEL CASTRO CHE GUEVARA CLEAVER COHN-BENDIT
DEBRAY ENERSTVEDT ELSTER FANON GOFFMAN HABERMAS BENTE HANSEN HØGH

ISRAEL LAING LEACH LEVI-STRAUSS LIDMAN MCLUHAN MARCUSE MAO MARX
\end{abstract}

MERLEAU-PONTY MORIN PALME PIAGET

\section{SOCIALPOLITISK FORENING}

har til formål:

"På sagligt grundlag at skabe interesse for og udbrede kendskabet til sociale forhold samt at virke som et samlingssted for drøftelse af sociale spørgsmål" .

Foruden vintersæsonens medlemsmøder i københavn afholdes der hvert år konferencer om tidens aktuelle sociale emner på Hindsgavl ved Middelfart med deltagelse fra de andre nordiske lande. Foreningen virker desuden ved udgivelse af social litteratur $i$ form af bøger og småskrifter (se næste side). Medlems- kontingentet for studerende er kun $15 \mathrm{kr}$. årlig og inkluderer tilsendelse af årets småskrifter og medlemsbladet m.v. Nærmere oplysninger kan fås ved henvendelse $i$ foreningens sekretariat: Holbergsgade 23. 3sal - $1057 \mathrm{Kbhn}$. K telefon: (01) MInerva 6760, kl. 10-14 Indmeldelse og bestilling af bøger og småskrifter sker ved indsendelse af sidestående og omstående blanket

NAVN :

STILLING :

ADRESSE : 


\section{BYPLAN}

tidsskrift for fysisk, økonomisk og social planlægning af byer, landdistrikter, regioner og lande.

I kommende numre behandles Københavnsegnen, planlægning efter kommunalreformen, tendenser i amerikansk planlægning, fremtidsforskning og planlægningen, forberedelsen til et samfund i forandring etc.

Byplan udkommer med 6 numre om året.

Abonnementspris kr. 62,00.

Studenter får 25 pct. rabat ved forevisning af studiekort i forlagets ekspedition.

Arkitektens Forlag

Nyhavn 43 . 1051 København K

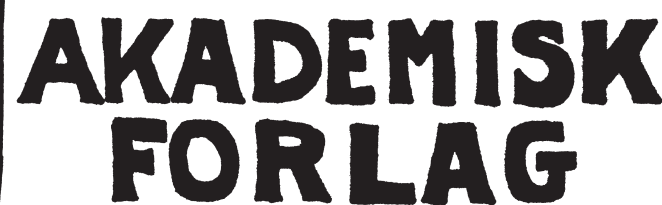

HAR

UDGIVET

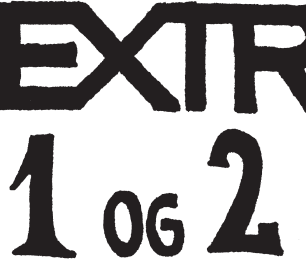

SPECIALOPGAVER

FRA DET

FILOSOFISKE

FAKULTET
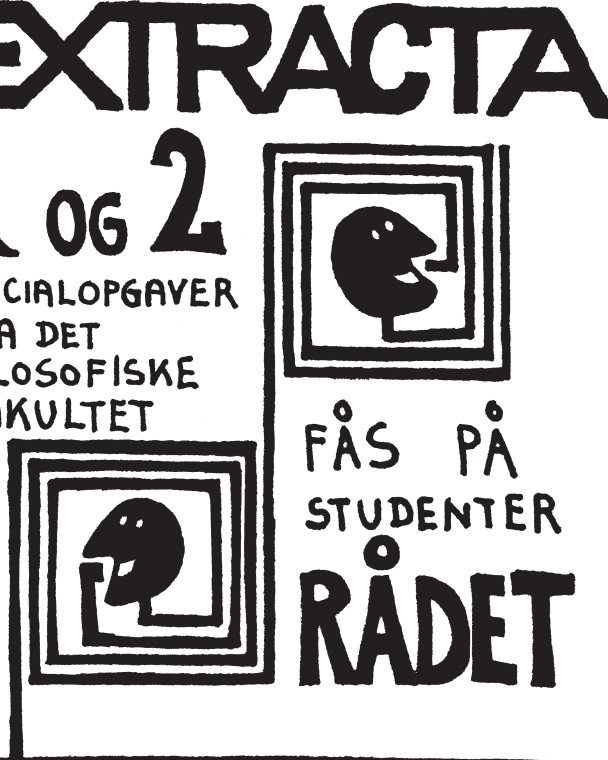

FÅS P̊̊ STUDENTER RADET

Bestillingsliste for Socialpolitisk forenings bøger og småskrifter:

Medlemsskab af Socialpolitisk forening (se foregånde side) indebærer, at bøger og småskrifter kan købes til den her nævnte fordelagtige foreningspris d.v.s. $20 \%$ rabat.

Herved bestilles de med $\mathrm{x}$ mærkede småskrifter og/eller bøger.

Giroblanket til betaling vedlægges ved fremsendelsen.

SMÅSKRIFTER :

Nr. Titel

$\mathrm{kr}$.

32 Familiepolitik - hvorfor

hvordan? (1962) ...........4,25

33 Bondelandets forvandling

(1964) ................... 5,50

34 Uddannelse af ikke-faglærte

(1965) .................4, 4,00

35 Byen - liv og form ill.

2.oplag (1968) ............. 9,00

37 Fattig $i$ et velstandssamfund

$(1966) \ldots \ldots \ldots \ldots \ldots \ldots \ldots, 25$

38 Den sociale udvikling $i$

Grøndland, ill. (1967) ...... 3,25

39 Samfundet og fysisk handicappede

(1967) ..................... 7,00

40 Bedre prioritering i social-

politikken $(1969) \ldots \ldots \ldots \ldots, 00$
41 To indlæg om familievejledning (1969) .................... 7,50

BØGER :

Familien og samfundet af

Henning Friis (red.) 1964........ 18,50

Det danske samfund, redigeret af

P.N. Andersen og Poul Dam (1966) .. 25,75

Socialmedicin I

af Iwan Mark 1968............ 23,00

Socialmedicin II

af Iwan Mark 1968............ 25,75

Strejker eller voldgift af ole

Malmquist, K. Francis Madsen og

Poul Dam

Svend Hansen 1968............ 17,00

Hvem hjælper?

oversigt over offentlige og

private hjælpeforanstaltninger

redigeret af Vagn Holm 1969..... 26,00

Fra fængsel til frihed

af C. Aude. 4. ændrede udg.1969...20,00

De politiske partier

redigeret af $\mathrm{E}$. Vagn Jensen

3. ændrede udg. 1969..........24,00 